\title{
Olga Sokołowska
}

UDK 811.162.1’366

Izvorni znanstveni rad

Rukopis primljen 1. I. 2020.

Prihvaćen za tisak 12. XII. 2020.

doi.org/10.31724/rihjj.47.1.5

Instytut Anglistyki i Amerykanistyki, Wydział Filologiczny, Uniwersytet Gdański

U1. Wita Stwosza 51, PL-80-308 Gdańsk

orcid.org/0000-0002-4722-113X

olga.sokolowska@ug.edu.pl

\section{Mikołaj Rychło}

Instytut Anglistyki i Amerykanistyki, Wydział Filologiczny, Uniwersytet Gdański

U1. Wita Stwosza 51, PL-80-308 Gdańsk

orcid.org/0000-0003-1821-7219

mikolaj.rychlo@ug.edu.pl

\section{CZY PRZYMIOTNIK MOŻE PRZYBRAĆ FORMĘ HIPOKORYSTYCZNĄ? \\ STUDIUM NA PRZYKŁADZIE WYRAZÓW OKREŚLAJĄCYCH BARWY}

Artykuł omawia zagadnienie klasyfikacji, funkcji oraz częstotliwości użycia pewnych form, które mogą przybierać niektóre przymiotniki w języku polskim, ze szczególnym uwzględnieniem wyrazów określających kolory. Chodzi tu o derywaty utworzone przez dodanie do podstawy słowotwórczej danego leksemu formantów takich, jak -utki, -uteńki, -utenieczki, -uśki, -usieńki, -usienieczki, -eńki, -usi oraz -uchny. Względy formalne uzasadniają określenie derywatów z wymienionymi sufiksami jako hipokorystyków, które mogą przybierać różne funkcje semantyczne i pragmatyczne. Kategoria hipokorystyków w dotychczasowych opracowaniach słowotwórstwa polskiego odnosi się wyłącznie do rzeczowników odrzeczownikowych. Niniejszy artykuł postuluje wprowadzenie tej kategorii w odniesieniu do przymiotników odprzymiotnikowych.

\section{Atestacja}

Przymiotniki wzbogacone o formanty wymienione we wstępie zostały w dużej liczbie odnotowane już w pierwszym jednojęzycznym Słowniku Języka Pol- 
skiego S. B. Lindego, gdzie odnaleźć można następujące sufiksy do wyrazów określających barwy:

-utki: bielutki, czarniutki (czerniutki), czerwoniutki, ciemniutki, siwiutki

-uteńki: bieluteńki, czarniuteńki (czerniuteńki), czerwoniuteńki, ciemniuteńki, siwiuteńki

-uteneczki: ciemniuteneczki

-uśki: bieluśki, czarniuśki (czerniuśki), czerwoniuśki, jaśniuśki

-usieńki: bielusieńki, czarniusieńki (czerniusieńki), czerwoniusieńki, ciemniusieńki, siwiusieńki

-usienieczki: czarnusienieczki, jaśniusienieczki

-eńki: brak nazw kolorów (tylko trzy przykłady: młodeńki, słabeńki, podobnieńki)

-usi: brak nazw kolorów (tylko jeden przykład: wdzięcznusi)

-uchny: bieluchny, czerniuchny, czerwoniuchny (czerwieniuchny), ciemniuchny, jaśniuchny, siwiuchni, złociuchny, żółciuchny

Jeśli chodzi o przymiotniki inne niż nazwy barw, to już w słowniku A. Kalepina z 1590 r. odnaleźć można osiem derywatów z przyrostkiem -usieńki (doskonalufienki, chadziufienki, kwafniufienki, liekufienki, maliufienki, miekufienski, młodziufienki, starzufienki), jeden derywat z przyrostkiem -uśki (czieniujzky) ijeden z przyrostkiem-uczki(maliuczki)-por. Żwak(1984: 127). Najwięcej jednak tego typu formacji wylicza autorka (1984: 66-67) omawiając sufiks -uchny. Są wśród nich dwie nazwy barw: siwiuchny i zołcziuchni. Ciekawy wydaje się fakt, że przymiotniki te tłumaczą najczęściej łacińskie przymiotniki deminutywne z sufiksem -ulus takie jak parvulus 'bardzo mały, malutki'.

Słownik staropolski, obejmujący słownictwo zaczerpnięte z rękopisów od czasów najstarszych aż do roku 1500, nie odnotowuje żadnych haseł z formantami rozszerzonymi tj. -uteńki, -usieńki, -utenieczki, -usienieczki; nie ma też derywatów na -uśki, -eńki i -usi; figurują natomiast następujące derywaty na -utki i -uczki: malutki, milutki, maluczki, miluczki. Jedynym ekspresywizmem określającym barwę jest derywat: zieleniuchny. Przykład zamieszczony w słowniku 
staropolskim (Tom XI, Zeszyt 5 (73), str. 356) pochodzi z ok. 1500 roku: Thy yesz golabyczka boza, noszqcz roszczkq zyelenyvchna (Ty jeś gołębiczka boża, nosząc rożdżkę zieleniuchną).

Przedstawione dane prowadzą do wniosku, iż rozwój ekspresywnych formacji słowotwórczych na określenie nazw barw wydaje się zjawiskiem, które zaszło dopiero w dobie średniopolskiej i nowopolskiej. Skąpa atestacja w okresie staropolskim nie wyklucza jednak możliwości istnienia ekspresywnych form we wcześniejszych stadiach rozwoju polszczyzny. Być może nie zostały one zapisane ze względu na swój ekspresywny (potoczny) charakter.

\section{Charakterystyka morfologiczna}

Należy na wstępie zaznaczyć, że omówione poniżej formanty częściej, choć nie wyłącznie, występują z przymiotnikami nacechowanymi niż nienacechowanymi w takich parach antonimów, jak maty - duży, cienki/chudy - gruby, niski - wysoki, lekki - ciężki, waski - szeroki, nowy/młody - stary, zimny - ciepty, miękki - twardy. Określenia barw (i nie tylko barw, ale także innych właściwości) mogą w polszczyźnie zawierać następujące sufiksy:

(2)

-utki (np. bielutki, różowiutki, siwiutki, złociutki, żółciutki, zieloniutki, zieleniutki, czerwoniutki, niebieściutki, czarniutki, brazowiutki, rudziutki, błękitniutki, srebrniutki)

-uśki (np. bieluśki, żółciuśki, czerwoniuśki)

-uchny (np. bieluchny, różowiuchny, złociuchny, żółciuchny, zieloniuchny, czerwoniuchny, niebieściuchny, czarniuchny)

-eńki (np. bieleńki, złocieńki, żółcieńki, szareńki, bladzieńki)

-usi (np. bielusi, siwiusi, żółciusi, czarnusi)

-uteńki (np. bieluteńki, siwiuteńki, żółciuteńki, czarniuteńki, zieloniuteńki)

-usieńki (np. bielusieńki, różowiusieńki, siwiusieńki, żółciusieńki, czarniusieńki, bladziusieńki) 
-utenieczki (np. bielutenieczki),

-usienieczki (np. bielusienieczki) ${ }^{1}$

Przedstawioną listę sufiksów można uporządkować, zwracając uwagę na fakt, że kilka z nich podlega rozszerzeniom tworząc afiksy złożone: formanty -utki i -uśki przyjmując element -eń- tworzą -uteńki oraz -usieńki. Te zaś z kolei podlegają kolejnym rozszerzeniom tworząc: -utenieczki i -usienieczki. Przedstawmy inwentarz formantów w następującym porządku:

$$
\begin{array}{ll}
-u t-k i \rightarrow-u t-e n ́-k i \rightarrow-u t-e n i-e c z-k i & -u s i \\
-u s ́-k i \rightarrow-u s i-e n ́-k i \rightarrow-u s i-e n i-e c z-k i & -u c h-n y \\
-e n ́-k i &
\end{array}
$$

Warto też odnotować fakt, że sufiks -eń-, który rozbudowuje formanty -utki i -uśki, występuje również w formancie -eń-ki. Można też doszukiwać się związku formalnego między pierwszym członem przyrostka -uś-ki oraz formantem -usi, w którym wygłosowe $i$ należy już do końcówki fleksyjnej sygnalizującej rodzaj męski, a poprzednia spółgłoska jest identyczna z tą w -uś-ki. Można zatem zapisać -usi jako -uśri. Podsumowując, inwentarz formantów tworzący ekspresywne nazwy kolorów da się zredukować do następujących morfemów: -ut-, -uch-, $-u s ́$, -eń-, -ecz-. Pozostałe morfemy: -ki oraz -ny nie posiadają ekspresywnych konotacji, lecz jedynie funkcję strukturalną cechującą przymiotniki zarówno motywowane, jak i niemotywowane: uprawny, słynny, marudny, płodny; krótki, lekki, niski, ptytki, prędki, stodki, waski (NB Te ostatnie przymiotniki gubią -ki w stopniu wyższym: krótszy, lizejszy, niższy, węższy). Analizując przymiotniki: króciutki, niziutki, płyciutki, prędziutki, słodziutki, waziutki, można uznać, że formantem ekspresywnym jest sufiks -ut-, wyraz podstawowy zawiera już bowiem -ki-por. krótki, niski, waski etc.

\footnotetext{
Formacje z sufiksami -utenieczki i -usienieczki są bardzo rzadkie. Na przykład Słownik pod redakcją Doroszewskiego nie notuje żadnych nazw kolorów na -utenieczki. Jednak Marciniak-Firadza (2016: 5367) opisując nazewnictwo stroju ludowego Księżaków łowickich podaje: „na określenie koloru różowego używały Księżanki nazw: różowy, blady, tysy, natomiast dla określenia jego odcieni: bladziutki, bladziuchny, bladziusieńki, bladzieńki, tysiuchny, tysiutki, tysiusieńki, tysiuteńki, tysiutenieczki, tysyniutki. Sam kolor biały ma kilka odcieni, por. biaty, bielutki, bielusieńki, bielutenieczki, bieluteńki, bieluchny, a zielony kilkadziesiąt, por. wybrane: [...] zieloniuchny, zieloniuteńki” Marciniak-Firadza (2016: 53-67).
} 


\section{Klasyfikacja}

Choć wyrazy określonego wyżej typu są w polszczyźnie, zwłaszcza potocznej (ale także i w literaturze) dość często używane, ich sklasyfikowanie nie jest sprawą prostą, brak, bowiem, jednoznacznego kryterium, na podstawie którego można by tego dokonać. Dwoistość kategorialną wyżej wymienionych derywatów można zauważyć porównując dotychczasowe opracowania polskiego słowotwórstwa, gdzie klasyfikowane są one jako derywaty ekspresywne, wskazując, że wyrażają przede wszystkim emocje użytkowników języka (Kallas 1999: 506-507, Szymanek 2010: 214-215), intensiva, które zaznaczają wyższy niż określony przez podstawę słowotwórczą stopień nasilenia danej cechy, np. wqziutki - 'bardzo wąski; bielutki - 'bardzo, czysto biały' (por. Grzegorczykowa 1981[1972]: 69-70, Szymanek 2010: 214-215, Bogusławski 1991²), a czasem jako deminutywy (Łoś 1925, Vaillant 1974: 703, § 1179³, Kreja 2002: 2794). Można też próbować ujać pewne kategorie wewnątrz innych, większych: na przykład Szymanek (2010: 214) rozpatruje intensyfikację przymiotników jako typowy przykład na morfologię ekspresywną (, intensification of adjectives as a typical instance of expressive morphology”). Także Polański (1999: 110-111) w swej Encyklopedii Językoznawstwa Ogólnego, w haśle deminutivum, zdefiniowanym jako ,rzeczownik odrzeczownikowy oznaczający przedmiot traktowany przez mówiącego jako mały w stosunku do ogółu przedmiotów nazywanych przez rzeczownik podstawowy", zamieszcza też definicję terminu hipokorystyk (w haśle hypokoristicon), w której określa, że jest to „rzeczownik wyrażający pieszczotliwy stosunek osoby mówiącej do przedmiotu nazywanego".

\footnotetext{
2 Według Bogusławskiego (1991: 174), „sufiks -utki ma co najmniej dwie wyraźnie różne właściwości funkcjonalne: z jednej strony przypisuje danej cesze osobliwy „stopień intensywności”, tak że np. nie wszystko, co jest „,ienkie”, gotowi jesteśmy określić jako cieniutkie; z drugiej strony, sufiks -utki likwiduje neutralność przymiotnika nadając powstającemu tworowi szczególny ton emocjonalny, który nie jest automatycznym następstwem kwalifikacji gradacyjnej."

3 „Une autre forme de dérivés est en pol. -(j)utki, fournissant des diminutifs d'adjectifs : malutki « très petit », niziutki « très bas », glupiutki «très bête», etc., et variante de -(j)uchny : maluchny, glupiuchny, etc. Ici, on apercevrait un contact entre le suffixe - ut- et le suffixe - ux- (§ 1158), également très représenté, dont la finale $-x$ - est hypocoristique, et qui pourrait présenter aussi l'élément thématique - $u$ - du type verbal en -ovati" (Vaillant 1974: 703, § 1179).

4 Bogusław Kreja (2002b: 279) używa określenia „,formy deminutywne” w odniesieniu do formacji na -utki w dolnołużyckim. Najczęściej jednak klasyfikuje formacje na uchny, na -utki i na -uśki jako przymiotniki ekspresywne (por. Kreja 2002a i 2002b).
} 
Jak się zdaje, w przypadku opisanych wyżej prób jednoznacznej klasyfikacji za podstawę przyjęty został klasyczny, arystotelesowski model kategoryzacji oparty na rozpoznaniu cech istotnych - koniecznych i wystarczających do zaliczenia danego zjawiska do określonej jednostki taksonomicznej (kategorii). Taka kategoria jest jednoznacznie zdefiniowana, wyraźnie wydzielona, stabilna i nie wchodzi w relacje z innymi (por. Lakoff 1982: 14-15). Jednak, jak już wspomniano, klasyfikacja wyrazów o określonej we wstępie budowie morfologicznej nie jest jednoznaczna bowiem mogą zostać wzięte pod uwagę różne kryteria: kryterium semantyczne, na podstawie którego omawiane jednostki zaliczane są do intensivów, bądź kryterium pragmatyczne, które decyduje o ich przynależności do klasy wyrazów ekspresywnych. Sytuację komplikuje dodatkowo fakt, że formanty, decydują stanowią o specyficznym znaczeniu leksemów, stanowiące ich część morfologiczną żywo przypominają morfemy (przyrostki) zdrabniające i spieszczające przyłączane do rzeczowników (np. kogut - kogutek - kogucik; kaczka - kaczuszka - kaczuchna; suka - suczka - sunia), w wyniku czego omawiane leksemy przymiotnikowe bywają także zaliczane do deminutywów (por. Łoś 1925: 82-83, Vaillant 1974).

Jak już wspomniano, w próbach jednoznacznego zaszeregowania przymiotników z formantami -utki; -uchny; -eńki i in. przejawia się zastosowanie klasycznego, arystotelesowskiego modelu kategorii. Tymczasem, model ten wydaje się w świetle dynamicznie rozwijających się od lat 70-ych XX wieku kognitywnych badań dotyczących poznania i kategoryzacji świata przez ludzi już nieco skostniały i, jak wykazuje w swych fundamentalnych dla językoznawstwa kognitywnego pracach George Lakoff $(1982,1987)$, niezbyt przystający do zjawisk występujących w językach naturalnych. W wyniku tych badań wypracowany został alternatywny model kategorii kognitywnej (naturalnej) ustanawianej na podstawie percepcji cech obiektów poznania relewantnych ${ }^{5}$ z punktu widzenia człowieka, skoncentrowanej wokół prototypu wykazującego optymalną kombinację takich cech, zorganizowanej na podstawie zasady podobieństwa rodzinnego, czyli wykazywania pewnych preferowanych cech wspólnych z innymi elementami danej klasy zjawisk. Liczba i stopień relewancji wspólnych cech mogą być różne, co powoduje, że byty, które mają stosunkowo niewiele cech wspól-

\footnotetext{
Co do obiektywnej, niezależnej od poznania rzeczywistej istotności takich cech nie można mieć absolutnej pewności, ponieważ człowiek jest w stanie rozważać tylko takie bodźce, które może odnotować jego aparat poznawczy.
} 
nych z prototypem (ale dziela je z innymi, mniej prototypowymi uczestnikami kategorii, czyli są do nich podobne) stają się elementami peryferyjnymi, funkcjonującymi na obrzeżach grupy, przez co te obrzeża rozmywają się i nieostro odgraniczają się od innych kategorii, w których także można rozpoznać cechy wykazywane przez nieprototypowe elementy kategorii sąsiedniej. Wydaje się, że taki właśnie model znacznie lepiej nadaje się do sklasyfikowania wyrazów, które są przedmiotem rozważań w niniejszym artykule.

A zatem, przymiotniki przyłączające formanty -utki; -uchny; -eńki, etc. można ulokować we wszystkich trzech wspomnianych kategoriach leksykalnych (intensiva, wyrazy ekspresywne - hipokorystyki, deminutywy), ponieważ mają pewne cechy wspólne z typowymi elementami każdej z nich, przy czym same pozostają na peryferiach tych kategorii jako elementy nieprototypowe, co spowodowane jest faktem, że wykazują również cechy wspólne z jednostkami zaliczanymi do innych klas wyrazów. I tak, z intensivami łączy je podobieństwo efektu semantycznego - zakomunikowania o wyższym stopniu nasilenia określanej przez przymiotnik cechy. Jednak klasyczne intensiva osiągają ten efekt za pomocą przedrostków, które w sposób wyrazisty wnoszą ,wzmacniający” ładunek semantyczny, jak np. w wyrazach nadaktywny; arcyciekawy, przemity. Można także wziąć pod uwagę fakt, że omawiane leksemy są przecież przymiotnikami, których raison d'être jest określanie cech przedmiotów reprezentowanych przez rzeczowniki, a przedmioty te jak najbardziej mogą mieć stosunkowo mniejsze rozmiary. Rzeczywiście, bardzo powszechne są kolokacje analizowanych tutaj przymiotników z rzeczownikami deminutywnymi. Z kolei do grupy wyrazów ekspresywnych upodobnia je to, że bardzo często (choć nie zawsze) używane są w funkcji hipokorystycznej, do wyrażenia pozytywnych uczuć i odczuć mówiącego, takich, jak czułość, sympatia, przyjemne wrażenie estetyczne. Takie wyrażenia, np. malutkie ciasteczko, bielutkie chmurki, żółciutki kurczaczek reprezentują amalgamaty pojęciowe w rozumieniu teorii Turnera i Fauconniera 
(1995), w których część ładunku semantycznego (w tym przypadku znaczna, jako że tego typu związki frazeologiczne nie są na ogół w wysokim stopniu skonwencjonalizowane i ustalone $\mathrm{w}$ języku $\mathrm{u}^{6}$ ) zaczerpnięta jest $\mathrm{z}$ obu pojęć wyjściowych reprezentowanych zarówno przez rzeczownik jak i przymiotnik. Cecha „mniejszego rozmiaru” niewątpliwie stanowi wkład semantyczny wnoszony do amalgamatu przez rzeczownik z formantem deminutywnym, jednak wydaje się ona być wzmocniona przez znaczenie przymiotnika wzbogaconego o formant morfologicznie bardzo podobny. Z kolei cecha „ekspresywności”, pozytywnej ewaluacji estetycznej bądź emocjonalnej, pochodzi z obydwu koncepcji wyjściowych, zarówno tej reprezentowanej przez modyfikator, np. bielutka $a^{7}$ jak i ośrodek frazy, np. chmurka. Jeśli, natomiast, chodzi o kategorię deminutywów i hipokorystyków, których prototypowe, rzeczownikowe przykłady istotnie określają stosunkowo mniejsze rozmiary desygnatów, choć najczęściej także pozytywne wobec nich odczucia mówiącego (np. kogutek, kaczuchna, pqczuś, kiciuś, sunia), to omawiane leksemy łączy z nimi podobieństwo morfologiczne.

Należy, wszakże, zaznaczyć, że omawiane przymiotniki nie są elementami prototypowymi w żadnej z trzech branych pod uwagę kategorii. Nie są wzorcowymi intensivami, ponieważ, w przeciwieństwie do prototypów tej grupy leksemów, nie zawierają morfemu, którego konwencjonalnym ładunkiem semantycznym byłoby pojęcie większej intensywności, jak np. w przypadku wyrazów nadwrażliwy, arcytrudny, przepiękny. Omawiane przymiotniki nie osiagają podobnego rezultatu równie bezpośrednio i jednoznacznie, (np. milutki, cieniutki, żólciutki, bieluśki), a więc nie są to intensiva prototypowe. Oprócz tego, według Krystyny Kallas (1999: 506), kategoria intensivów sygnalizuje, że intensywność cechy przekracza normę i obejmuje tylko formanty prefiksalne (rodzime i obce). Badaczka posługuje się przykładem nadwrażliwy, który parafrazuje jako

6 W przypadku fraz wysoce skonwencjonalizowanych, takich, jak np. zielona herbata; biate wino; profesor nadzwyczajny cechy najbardziej istotne, specyficzne, odróżniające daną kategorię od innych, pokrewnych określane są przez wyraz modyfikujący rzeczownik i to one stanowią o autonomii amalgamatu konceptualnego reprezentowanego przez takie wyrażenie; przy tym pojęcie określane przez rzeczownik zapewnia raczej tylko „rusztowanie” pojęciowe i określa cechy ogólne desygnatu. W przypadku fraz tworzonych ad hoc, nieustabilizowanych we frazeologii języka, np. zielony T-shirt; bialy mercedes; nadzwyczajny uczeń, rola pojęcia określanego przez rzeczownik, czyli ośrodka frazy, jako źródła cech wyróżniających dla całego amalgamatu zdaje się wzrastać.

7 Takie morfologicznie złożone leksemy także zdają się być wyrazem amalgamatów pojęciowych - domeny wyjściowe określane są przez rdzeń przymiotnikowy, np. biały, niebieski oraz przez morfem związany, np. -ut(ki); -uch(ny); przy czym to ten drugi stanowi o hipokorystycznym wydźwięku całego wyrażenia. 
'zbyt (zanadto) wrażliwy'. Parafrazę tę można uogólnić: A - 'zbyt (zanadto) $\mathrm{A}_{1}$ '. Inne przykłady to: nad- (np. nadgorliwy, nadopiekuńczy, nadludzki, nadobowiqzkowy); przed- (np. przedwczesny); hiper- (np. hiperkrytyczny, hiperpoprawny); prze- (np. przedziwny, przebogaty, przecudowny, przekomiczny, prześliczny); pra- (np. pradawny, prastary); arcy- (np. arcyciekawy, arcydelikatny, arcylojalny, arcyzabawny); ekstra- (np. ekstramocny) super- (np. supernowoczesny, superszybki, supermodny, superoszczędny); ultra-(np. ultranowoczesny, ultrakatolicki, ultraradykalny, ultrakrótki). Jak jednak wskazuje wiele z tych przykładów (np. nadludzki, przebogaty, przecudowny, pradawny, arcyzabawny, supernowoczesny i inne), definiowanie znaczenia wszystkich przyrostków intensyfikujących przy pomocy przysłówków zbyt, zanadto jest nieco zbyt specyfikujące; wydaje się, że bardziej adekwatna byłaby parafraza przy pomocy ogólniejszych określeń ponad normę, $w$ wyższym stopniu, które także opisują semantyczną funkcję intensivów. Podobnie, porównując funkcję derywatów niebieściutki, żótciuśki, różowiuchny, złocieńki i innych wymienionych w punkcie (1), nie odnajdujemy w nich znaczenia 'zbyt (zanadto)', tak jak w niektórych wyżej przytoczonych przykładach, np. nadwrażliwy 'zbyt (zanadto) wrażliwy' i innych. Wyrazy omawianego typu nie są także klasycznymi, przykładowymi ekspresywizmami, bo prototypami w tej kategorii są predykacje rzeczownikowe ${ }^{8}$ odnoszące się do wybranych desygnatów, które zresztą niekoniecznie muszą wyrażać emocje pozytywne, np. kochanie, córeńka, psina, domiszcze, ochlaptus, morda, babsko, natomiast przymiotniki z formantami -utki; -uchny; -eńki, etc. opisująjedynie cechy osób/przedmiotów, i to raczej do nich, niż do ich cech, można żywić jakieś uczucia. Ponadto, przymiotniki z wymienionymi wyżej formantami nie są, oczywiście, prototypowymi deminutywami, ponieważ cechę małego rozmiaru mogą określać jedynie pośrednio - poprzez modyfikowany przez siebie rzeczownik. Wykazują jednak podobieństwo rodzinne, czyli mają niektóre cechy wspólne z leksemami przynależnymi do wszystkich trzech wymienionych wyżej kategorii (intensivów, ekspresywizmów, deminutywów),

\footnotetext{
8 Oczywiście, kategoria ekspresywizmów, czyli ,jednostek leksykalnych, które zawierają w strukturze semantycznej składnik wskazujący na uczuciowy stosunek nadawcy do rzeczywistości pozajęzykowej" (por. Wiatrowski 2010: 165) nie zawiera wyłącznie leksemów rzeczownikowych; w ten sposób mogą funkcjonować także przymiotniki czy nawet czasowniki, jednak to właśnie rzeczowniki zdają się być w tej kategorii przykładami prototypowymi, jako predykaty odnoszące się do bytów postrzeganych jako samodzielne. Przymiotniki ekspresywne określają jedynie aspekty (cechy) takich bytów, a ekspresywne czasowniki, które zresztą wydają się być raczej rzadkością, do relacji, w których są one zaangażowane.
} 
przy czym cechą najbardziej wyróżniającą się jest cecha formalna (obecność charakterystycznego morfemu). Przymiotniki te lokują się zatem na pograniczu kilku (trzech) kategorii leksykalnych mając pewne cechy wspólne - semantyczne, pragmatyczne i morfologiczne - z wszystkimi trzema, co znajduje swoje odbicie w sposobie ich funkcjonowania w języku.

Wobec powyższych rozważań powstaje pytanie, jakim właściwie terminem należałoby nazwać przymiotniki z przyrostkami -utki; -uchny; -eńki i innymi tego rodzaju, wykazują one, bowiem, cechy wspólne z kilkoma kategoriami leksemów: intensivami (na podstawie kryterium semantycznego), wyrazami ekspresywnymi (kryterium pragmatyczne) oraz hipokorystykami (kryterium formalne, morfologiczne). Oparcie się na dwóch pierwszych wskaźnikach spowodowało zaliczenie omawianych przymiotników do dwóch różnych grup przez autorkę (Grzegorczykowa 1981) posługującą się tradycyjnym modelem kategorii i opierającą się w obu przypadkach na jednej tylko, wybranej ich cesze uznanej za wyznacznik zaszeregowania taksonomicznego. Takie sklasyfikowanie podkreślające jedną tylko właściwość (semantyczną lub pragmatyczną) zaciemnia jednak drugą, równie istotną. Wydaje się zatem, że najwygodniejszym rozwiązaniem mogłoby być oparcie się na neutralnym kryterium formalnym i określenie tego typu wyrazów terminem przymiotników hipokorystycznych, spieszczonych, ponieważ ich przykuwającym uwagę, materialnym wyróżnikiem jest obecność formantu mocno przypominającego formant hipokorystyczny przyłączany do rzeczowników. Poniżej zamieszczamy uzasadnienie powyższej decyzji terminologicznej, odwołujące się do morfologii omawianej grupy wyrazów.

\subsection{Formanty -utki, -uchny, -eńki i -uśi jako znaczniki hipokoryzacji}

Nie negując ekspresywnych i intensyfikujących wartości omawianych derywatów, w niniejszej pracy opowiadamy się za klasyfikacją hipokorystyczną powołując się na niżej przedstawione argumenty morfologiczne.

Jednym z tych argumentów jest zawieszenie mechanizmu blokowania wobec jedynie niektórych spośród formacji ekspresywnych - są to właśnie derywaty, które proponujemy zaliczyć do hipokorystyków. Innymi słowy, cechą charakterystyczną analizowanych tu formacji jest współwystępowanie wielu podobnych derywatów (por. bielutki, bielusieńki, bialutki, bieluśki, bieluteńki, bieluchny, 
bieleńki, bialusieńki, bialuśki, bialuteńki, bielusi). W wypadku innych kategorii słowotwórczych, współwystępowanie wielu paralelnych formacji jest z reguły blokowane, np. gaśnica, *gaśnik, *gasiarka, *gasiacz, *gasiak; czytnik, *czytnica, *czytarka, *czytacz, *czytak; jeśli już występują dwa lub więcej typów, to uzasadnione to jest zróżnicowaniem semantycznym: zmywak, zmywacz, zmywarka, *zmywnik, *zmywnica.

Kolejnym argumentem jest brak derywatów od nazw kolorów z sufiksami -aśny i -aśki. Formanty te należą niewątpliwie do kategorii przymiotników ekspresywnych (np. grubaśny, grubaśki), ale ich funkcja semantyczna nie odpowiada spieszczeniom. Powstaje zatem następujące pytanie: dlaczego, wobec zawieszenia mechanizmu blokowania w wypadku formacji ekspresywnych, nie mamy formacji takich jak *bielaśny czy *bielaśki? Odpowiedź wydaje się tkwić w braku hipokorystycznych konotacji derywatów z przyrostkami: -aśny (np. grubaśny) i -aśki (np. grubaśki). Jeśli wyróżnimy jednak wśród przymiotników ekspresywnych kategorię hipokorystyków, uzyskujemy wyjaśnienie braku formacji *bielaśny czy *bielaśki: najwyraźniej, nieskuteczność mechanizmu blokowania paralelnych formacji dotyczy kategorii hipokorystycznych nazw kolorów, do której nie należą derywaty z przyrostkami: -aśny i -aśki.

Inny argument odwołuje się do możliwości utożsamienia sufiksów występujących w niewatpliwych hipokorystykach rzeczownikowych $\mathrm{z}$ formantami tworzącymi ekspresywne nazwy kolorów, które, kilka akapitów powyżej, zredukowaliśmy do następującego inwentarza morfemów: -ut-, -uch-, -uś-, -eń-, -ecz-. Śledząc funkcje wymienionych powyżej afiksów, zauważyć można, że kilka z nich łączy się również z rzeczownikami tworząc spieszczenia lub rozszerzając je:

kot kot-uś

chleb chleb-uś

mąż męż-uś

syn syn-uś 
(5)

$\begin{array}{lll}\text { ryba } & \text { ryb-k·a } & \text { ryb-eń-k·a } \\ \text { gwiazda } & \text { gwiazd-k·a } & \text { gwiazd-eń-k·a } \\ \text { sierota } & \text { sierot-k·a } & \text { sierot-eń-k·a } \\ \text { córa } & \text { cór-k·a } & \text { cór-eń-k·a }\end{array}$

(6)

$\begin{array}{lll}\text { kot } & \text { kot-ek } & \text { kot-ecz-ek } \\ \text { pies } & \text { pies-ek } & \text { pies-ecz-ek } \\ \text { koło } & \text { kół-k·o } & \text { kół-ecz-k·o } \\ \text { lustro } & \text { luster-k·o } & \text { luster-ecz-k·o } \\ \text { wstęga } & \text { wstąż-k·a } & \text { wstąż-ecz-k·a } \\ \text { marchew } & \text { marchew-k·a } & \text { marchew-ecz-k·a }\end{array}$

Ponieważ przykłady kotuś, chlebuś, mężuś, synuś są niewątpliwie spieszczeniami, hipokorystyczny charakter przyrostka -uś-, pobrzmiewa również w przymiotnikach bielusi, siwiusi, żółciusi, czarnusi. Podobnie można porównać niewątpliwe hipokorystyki: córuchna, ciotuchna, raczuchna, ćwiartuchna z przymiotnikami bieluchny, różowiuchny, złociuchny, ̇̇ółciuchny, zieloniuchny, czerwoniuchny, niebieściuchny, czarniuchny. Następnie, spieszczenia rybeńka, gwiazdeńka, córeńka, sieroteńka skorelowane są z przymiotnikami bieleńki, złocieńki, zółcieńki, szareńki, bladzieńki. W końcu, morfem -ecz-, który rozszerza często zdrobnienia, co zostało zilustrowane w punkcie (6), czasami wydaje się tworzyć zdrobnienia, kiedy formacje z sufiksem $-k$ - $a$ przestały być postrzegane jako zdrobnienia (przykłady w punkcie 7) lub gdy sufiks - $k$ - $a$ ma inne funkcje (przykłady w punkcie 9 to nazwy żeńskie od męskich, przykłady w punkcie 10 to nomina actionis, w punkcie 11 zaś, to nomina instrumenti):

$\begin{array}{lll}\text { cór-a } & \text { cór-k·a } & \text { cór-ecz-k·a } \\ \text { księg-a } & \text { książ-k·a } & \text { książ-ecz-k·a } \\ \text { ciot-a } & \text { ciot-k·a } & \text { ciot-ecz-k·a } \\ \text { chust-a } & \text { chust-k·a } & \text { chust-ecz-k·a }\end{array}$


(8)

$\begin{array}{lll}*_{\text {szklan(-a) }} & \text { szklan-k·a } & \text { szklan-ecz-k·a } \\ \text { *klam(-a) } & \mathrm{klam}-\mathrm{k} \cdot \mathrm{a} & \mathrm{klam}-\mathrm{ecz}-\mathrm{k} \cdot \mathrm{a}\end{array}$

(9)

$\begin{array}{lll}\text { aktor } & \text { aktor-k·a } & \text { aktor-ecz-k·a } \\ \text { sąsiad } & \text { sąsiad-k·a } & \text { sąsiad-ecz-k·a }\end{array}$

powtór-k·a (od powtarzać) powtór-ecz-k·a

przesiad-k·a (od przesiadać) przesiad-ecz-k·a

$\begin{array}{ll}\text { ścier-k·a (od ścierać) } & \text { ścier-ecz-k·a } \\ \text { zapał-k·a (od zapalić) } & \text { zapał-ecz-k·a }\end{array}$

\section{Hipokorystyczne nazwy barw i częstotliwość ich użycia}

Przymiotniki oznaczające barwy zdają się być w polszczyźnie, szczególnie potocznej, mówionej, spieszczane dość często. Dotyczy to jednak prawie wyłącznie leksemów zaliczonych przez Berlina i Kaya (1969) do podstawowego słownictwa barw. Należy tu zaznaczyć, że, choć lista podstawowych nazw barw (basic color terms) opracowana przez wymienionych autorów dotyczy języka angielskiego, badacze słownictwa kolorów języka polskiego (np. Stanulewicz 2009), potwierdzają, że ich polskie odpowiedniki także należy do tej kategorii zaliczyć. Spośród jedenastu polskich podstawowych określeń barw (biaty, czarny, czerwony, zielony, żótty, niebieski, brazowy, fioletowy, różowy, pomarańczowy, szary) większość może przyłączać formanty hipokorystyczne; do wyjątków należą fioletowy i pomarańczowy, których formy hipokorystyczne nie występują w przebadanym korpusie językowym. Spieszczane bywają także niepodstawowe nazwy barw, takie, jak siwy, złoty, srebrny, rudy, błękitny. Pozostałe nazwy kolorów występują w formie hipokorystycznej w wymienionym materiale językowym z różną częstotliwością, przy czym częstotliwość ta nie jest do- 
kładnie skorelowana z pozycją danego leksemu w sekwencji odzwierciedlającej siedem etapów tworzenia się słownictwa barw w językach świata. Podczas, gdy hipokorystyki wyrazu biały, należącego do etapu I procesu rozwoju podstawowego słownictwa barw w językach naturalnych (tzn. jego odpowiedniki stanowią kategorię uniwersalną, występującą we wszystkich językach) są istotnie zdecydowanie najliczniejsze (510 przypadków użycia), już drugie miejsce pod względem popularności zajmują hipokorystyki wyrazu różowy (213 przypadków), czyli leksemu ostatniego etapu VII (wśród tworzonych tylko przez te języki, które rozwinęły już słownictwo wszystkich poprzedzających sześciu faz), gdzie występuje wraz z fioletowym, pomarańczowym i szarym, przy czym należy ponownie zaznaczyć, że hipokorystyczne formy dwóch pierwszych z nich nie zostały w badanym materiale zarejestrowane. Trzecim co do liczby wystąpień wśród wyrazów podstawowych okazuje się leksem etapu III żólty, którego formy hipokorystyczne użyte zostały 155 razy. Hipokorystyki wyrazu żólty pod względem liczebności znacznie wyprzedzają zarówno analogiczne formy leksemu etapu II czerwony (58 przykładów), jak i innego określenia barwy etapu III - zielony (93 przykłady). Stosunkowo częste są także hipokorystyki nazwy koloru etapu IV - niebieski (54). Jeśli chodzi o pozostałe podstawowe leksemy określające barwy, to ich form hipokorystycznych znalazło się w badanym korpusie raczej niewiele: brazowy (etap VI) - 15, szary (etap VII) - 2, przy czym zaskakująco nieliczne są hipokorystyki drugiego obok białego terminu etapu I - czarny, zaledwie 37. Stosunkowo liczne, natomiast, okazały się formy hipokorystyczne dwóch niepodstawowych nazw kolorów: wyraz siwy przybrał taką formę 171 razy (przy czym liczba przykładów z podwójnym formantem hipokorystycznym - siwiuteńki i siwiusieńki - okazała się prawie dwukrotnie większa niż prostszy morfologicznie wariant siwiutki), złoty - 169, podczas gdy inne, niepodstawowe nazwy kolorów, których hipokorystyki wystąpiły w korpusie to rudy - 7 razy, a analogiczne formy wyrazów srebrny i błękitny użyte zostały jedynie po 2 razy.

Przytoczone liczby zdają się potwierdzać wstępne ustalenie dotyczące istotnej roli funkcji pragmatycznej w tworzeniu hipokorystycznych nazw kolorów; jak już wspomniano, najczęściej służą one wyrażaniu pozytywnych odczuć użytkowników języka. Zapewne dlatego znacznie częściej spieszczane są nazwy barw budzące przyjemne skojarzenia, np. z czystością (biały), słońcem i ciepłem (żólty), pogodnym niebem (niebieski), zdrowym odcieniem ludzkiej skóry 
(różowy), atrakcyjnością (czerwony) czy naturą (zielony). W przypadku wyrazów niepodstawowych, siwy przyjmuje formę hipokorystyczną niemal wyłącznie jako określenie koloru włosów, metonimicznie reprezentując zaawansowany wiek ich posiadacza, co z kolei często budzi uczucia tkliwości i/lub szacunku, a hipokorystyki wyrazu złoty używane są w zasadzie nieodmiennie jako przypochlebna forma adresatywno-grzecznościowa. O korelacji między podatnością danej nazwy koloru na hipokoryzację i jej pozytywnymi konotacjami zdaje się świadczyć fakt stosunkowo niewielkiej liczby przykładów spieszczeń wyrazów czarny, brazowy i szary oznaczających barwy powszechnie uznawane za raczej ponure i smutne, przy czym ten ostatni znalazł się literalnie i ikonicznie na przysłowiowym szarym końcu listy.

\section{Ladunek semantyczny i pragmatyczny hipokorystycznych form nazw kolorów}

Funkcję semantyczną od pragmatycznej trudno jest odróżnić w przypadku, gdy znaczenie przymiotnika hipokorystycznego, także oznaczającego barwę, rozpatrywane jest w izolacji, bez wzięcia pod uwagę znaczenia i formy rzeczownika, który ten przymiotnik określa. Co do funkcji pragmatycznej, to zabarwienie hipokorystyczne, emocjonalne wydaje się występować, gdy desygnatem takiego rzeczownika jest istota żywa bądź jakiś związany z nią przedmiot, natomiast funkcja semantyczna, której efektem jest intensyfikacja znaczenia leksemu określającego barwę, powszechnie wiąże się z komunikowaniem oceny estetycznej (dość często częścią takiej frazy rzeczownikowej jest dodatkowy modyfikator śliczny, ładny). Materiał językowy zgromadzony w korpusie NKJP wskazuje, że częstymi kolokantami hipokorystycznych przymiotników określających barwy są rzeczowniki występujące w formie deminutywnej, np. żótciutki kurczaczek, niebieściutkie oczka, różowiutki bobasek.

Poniższa tabela przedstawia zarejestrowane w korpusie NKJP hipokorystyczne formy nazw barw i ich efekty semantyczne rozpoznane na podstawie najczęściej spotykanych, najbardziej typowych kolokacji. Kolejność została zdeterminowana przez liczbę występujących w zbadanym materiale językowym przykładów 


\section{- od największej do najmniejszej. Gwiazdką oznaczone zostały niepodstawowe nazwy kolorów.}

\section{Tab. 1. Hipokorystyczne formy nazw barw w języku polskim i ich znaczenie}

\begin{tabular}{|c|c|c|c|c|}
\hline $\begin{array}{l}\text { Termin } \\
\text { barwy }\end{array}$ & $\begin{array}{l}\text { Formy } \\
\text { hipokorystyczne } \\
\text { nazwy barwy }\end{array}$ & $\begin{array}{l}\text { Liczba } \\
\text { przykładów } \\
\text { w NKJP }\end{array}$ & Najczęstsze kolokacje & $\begin{array}{l}\text { Efekty semantyczne/ } \\
\text { pragmatyczne }\end{array}$ \\
\hline bialy & $\begin{array}{l}\text { bielutki } \\
\text { bielusieńki } \\
\text { bialutki } \\
\text { bieluśki } \\
\text { bieluteńki } \\
\text { bieluchny } \\
\text { bieleńki (częściej } \\
\text { jako rusycyzm) } \\
\text { bialusieńki } \\
\text { bialuśki } \\
\text { bialuteńki } \\
\text { bielusi }\end{array}$ & $\begin{array}{r}249 \\
91 \\
71 \\
46 \\
25 \\
10 \\
7\end{array}$ & $\begin{array}{l}\text { śnieg/śnieżek, } \\
\text { tkanina (pościel, obrus, } \\
\text { chustka) } \\
\text { skóra ludzka (twarz, } \\
\text { buzia, czoło, ręce), } \\
\text { włosy, zęby sierść } \\
\text { zwierzat, pióra ptaków, } \\
\text { maka, wypieki } \\
\text { (bułeczka, chleb), } \\
\text { piasek, } \\
\text { chmurka, } \\
\text { papier }\end{array}$ & $\begin{array}{l}\text { Formy hipokorystyczne } \\
\text { mają najczęściej funkcję } \\
\text { intensyfikującą (często w } \\
\text { kolokacji z przymiotnikiem } \\
\text { czyściutki) i wyrażają znaczenie } \\
\text { 'czysto, nieskazitelnie biały', } \\
\text { 'bardzo biały', najczęściej } \\
\text { wraz z pozytywnym ładunkiem } \\
\text { emocjonalnym. Formy te } \\
\text { znaczenia hipokorystycznego } \\
\text { nabierają w odniesieniu do cech } \\
\text { ludzi i zwierząt. } \\
\text { Sporadycznie hipokorystyk } \\
\text { reprezentuje znaczenie } \\
\text { metaforyczne: 'niewinny', } \\
\text { 'bezgrzeszny'. }\end{array}$ \\
\hline różowy & $\begin{array}{l}\text { różowiutki } \\
\text { różowiuchny } \\
\text { różowiusieńki }\end{array}$ & $\begin{array}{r}210 \\
2 \\
1 \\
213\end{array}$ & $\begin{array}{l}\text { twarz/skóra ludzka } \\
\text { (najczęściej w relacji } \\
\text { metonimicznej } \\
\text { CAŁOŚĆ ZA CZĘ́́́, } \\
\text { np. blondynka, } \\
\text { bobasek, mężczyzna, } \\
\text { grubas), } \\
\text { mięso (szynka, golonka, } \\
\text { tosoś), } \\
\text { świnka, prosiaczek } \\
\text { (najczęściej w } \\
\text { porównaniach } \\
\text { dotyczących opisu } \\
\text { wyglądu ludzi) }\end{array}$ & $\begin{array}{l}\text { Formy hipokorystyczne w } \\
\text { większości przypadków } \\
\text { intensyfikują znaczenie } \\
\text { wyrazu podstawowego i } \\
\text { zwykle, choć nie zawsze, } \\
\text { wyrażają pozytywną ewaluację } \\
\text { desygnatu modyfikowanego } \\
\text { rzeczownika ('ładnie, } \\
\text { intensywnie różowy'). Dość } \\
\text { częste są przypadki użycia } \\
\text { ironicznego dla wyrażenia } \\
\text { ewaluacji negatywnej, } \\
\text { szczególnie w opisach } \\
\text { wyglądu dorosłych kobiet i } \\
\text { mężczyzn a także kiczowatych } \\
\text { przedmiotów. } \\
\text { Niekiedy hipokorystyk } \\
\text { używany jest w sensie } \\
\text { metaforycznym: } \\
\text { 'komunizujący' (Pitsudski byt } \\
\text { czerwony, no, różowiutki), } \\
\text { 'prozaiczny, przyziemny' } \\
\text { (różowiutka śmiertelność), } \\
\text { 'ckliwy' (różowiutki, } \\
\text { przesłodzony obrazek), } \\
\text { 'beztroski' (różowiutkie życie). }\end{array}$ \\
\hline
\end{tabular}




\begin{tabular}{|c|c|c|c|c|}
\hline siwy* & \begin{tabular}{|l} 
siwiutki \\
siwiuteńki \\
siwiusieńki \\
siwiusi
\end{tabular} & $\begin{array}{r}62 \\
106 \\
2 \\
1 \\
171\end{array}$ & \begin{tabular}{|l|} 
wlosy \\
metonimicznie - osoba \\
(siwiutki/siwiutenki \\
staruszek)
\end{tabular} & $\begin{array}{l}\text { Hipokorystyk funkcjonuje } \\
\text { zazwyczaj w podwójnej roli: } \\
\text { intensyfikującej - semantycznej } \\
\text { ('całkiem, zupełnie siwy') } \\
\text { oraz ekspresywnej - } \\
\text { pragmatycznej i występuje jako } \\
\text { metonimiczna reprezentacja } \\
\text { podeszłego wieku. Zazwyczaj } \\
\text { wyraża pozytywne odczucia } \\
\text { użytkownika języka: czułość, } \\
\text { serdeczność. } \\
\end{array}$ \\
\hline zloty* & $\begin{array}{l}\text { złociutki } \\
\text { złocieńki } \\
\text { złociuchny }\end{array}$ & $\begin{array}{r}159 \\
8 \\
2 \\
169\end{array}$ & $\begin{array}{l}\text { Hipokorystyk wyrazu } \\
\text { złoty nie jest w zasadzie } \\
\text { używany w znaczeniu } \\
\text { atrybutywnym. Jako } \\
\text { zwrot grzecznościowy } \\
\text { nie ma wartości } \\
\text { predykatywnej, } \\
\text { opisowej. }\end{array}$ & $\begin{array}{l}\text { Hipokorystyk używany jest } \\
\text { prawie wyłącznie jako dość } \\
\text { poufały zwrot adresatywny } \\
\text { i jednocześnie hipokorystyk } \\
\text { metaforyczny (DROGI TO } \\
\text { ZŁOTY); bardzo rzadko dla } \\
\text { podkreślenia intensywności } \\
\text { barwy. Praktycznie jedyna } \\
\text { funkcja tej formy to funkcja } \\
\text { ekspresywna, nie jest ona w } \\
\text { zasadzie używana do opisu } \\
\text { barwy. }\end{array}$ \\
\hline zólty & $\begin{array}{l}\text { zólciutki } \\
\text { zótciuchny } \\
\text { zólciuśki } \\
\text { zótciuteńki } \\
\text { żótciusieńki } \\
\text { zótcieńki } \\
\text { zółciusi }\end{array}$ & $\begin{array}{r}136 \\
9 \\
4 \\
3 \\
1 \\
1 \\
1 \\
155\end{array}$ & $\begin{array}{l}\text { pisklęta (kurczaczki, } \\
\text { kaczuszki) } \\
\text { stoneczko } \\
\text { ciasto } \\
\text { kwiaty }\end{array}$ & $\begin{array}{l}\text { Forma hipokorystyczna } \\
\text { w funkcji semantycznej } \\
\text { zazwyczaj oznacza wysoki } \\
\text { stopień nasycenia określanej } \\
\text { barwy ('bardzo żółty', } \\
\text { 'intensywnie żółty') i } \\
\text { bardzo często, w funkcji } \\
\text { pragmatycznej, pozytywne } \\
\text { nastawienie mówiącego, bez } \\
\text { odniesień metaforycznych. } \\
\text { Liczba możliwych form } \\
\text { hipokorystycznych zdaje się } \\
\text { potwierdzać przypuszczenie, } \\
\text { że barwa żółta budzi } \\
\text { szczególnie ciepłe uczucia w } \\
\text { użytkownikach polszczyzny. }\end{array}$ \\
\hline zielony & $\begin{array}{l}\text { zieloniutki } \\
\text { zieleniutki } \\
\text { zieloniuchny }\end{array}$ & $\begin{array}{r}84 \\
8 \\
1 \\
93\end{array}$ & $\begin{array}{l}\text { trawa/wzgórza } \\
\text { liście/listki/listeczki } \\
\text { gatazki }\end{array}$ & $\begin{array}{l}\text { Forma hipokorystyczna } \\
\text { najczęściej występuje w funkcji } \\
\text { semantycznej i oznacza kolor } \\
\text { 'bardzo zielony, intensywnie } \\
\text { zielony' równocześnie pełniąc } \\
\text { rolę ekspresywną wyrażając } \\
\text { znaczenie 'ładnie, atrakcyjnie } \\
\text { zielony', często w kolokacji } \\
\text { z śliczny, tadny. Stosunkowo } \\
\text { częste jest znaczenie } \\
\text { metaforyczne 'niezorientowany } \\
\text { nieposiadający wiedzy na jakiś } \\
\text { temat'. }\end{array}$ \\
\hline
\end{tabular}




\begin{tabular}{|c|c|c|c|c|}
\hline czerwony & $\begin{array}{l}\text { czerwoniutki } \\
\text { czerwoniuśki } \\
\text { czerwoniuchny }\end{array}$ & $\begin{array}{r}54 \\
2 \\
2 \\
58\end{array}$ & $\begin{array}{l}\text { owoce (jabłka, } \\
\text { truskawki, czereśnie, } \\
\text { pomidory) } \\
\text { twarz (policzki) } \\
\text { cegła/mur ceglany }\end{array}$ & $\begin{array}{l}\text { Hipokorystyk podkreśla } \\
\text { intensywność barwy i } \\
\text { najczęściej komunikuje } \\
\text { pozytywne wrażenie estetyczne } \\
\text { mówiącego (wyjątek stanowią } \\
\text { opisy oparzonej słońcem } \\
\text { skóry). } \\
\text { Sporadycznie reprezentowane } \\
\text { jest znaczenie metaforyczne: } \\
\text { 'komunistyczny' (o Chinach). }\end{array}$ \\
\hline niebieski & $\begin{array}{l}\text { niebieściutki } \\
\text { niebieściuchny }\end{array}$ & $\begin{array}{r}51 \\
\underline{3} \\
54\end{array}$ & $\begin{array}{l}\text { oczy/oczka } \\
\text { niebo } \\
\text { kwiaty (chabry) }\end{array}$ & $\begin{array}{l}\text { Forma hipokorystyczna } \\
\text { używana jest najczęściej dla } \\
\text { podkreślenia intensywności } \\
\text { barwy oraz jako hipokorystyk } \\
\text { - dla wyrażenia pozytywnych } \\
\text { odczuć estetycznych. } \\
\text { Występuje wyłącznie jako } \\
\text { określenie barwy bytów } \\
\text { materialnych; brak odniesień } \\
\text { metaforycznych. }\end{array}$ \\
\hline czarny & $\begin{array}{l}\text { czarniutki } \\
\text { czarniuteńki } \\
\text { czarniusieńki } \\
\text { czarniusi } \\
\text { czarniuchny }\end{array}$ & $\begin{array}{r}30 \\
2 \\
2 \\
2 \\
\\
\underline{1} \\
37\end{array}$ & $\begin{array}{l}\text { oczka/oczęta, } \\
\text { włosy, } \\
\text { sierść zwierzęcia (kot, } \\
\text { źrebak) }\end{array}$ & $\begin{array}{l}\text { Hipokorystyk na ogół wyraża } \\
\text { znaczenie ‘całkiem, zupełnie } \\
\text { czarny’. Zazwyczaj podkreśla } \\
\text { też atrakcyjność czerni w } \\
\text { desygnatach modyfikowanych } \\
\text { rzeczowników. Forma } \\
\text { hipokorystyczna nie wystąpiła } \\
\text { w znaczeniu metaforycznym. }\end{array}$ \\
\hline brazowy & brazowiutki & 15 & $\begin{array}{l}\text { opalenizna } \\
\text { czekolada }\end{array}$ & $\begin{array}{l}\text { Hipokorystyk używany jest } \\
\text { przeważnie w znaczeniu 'ładnie } \\
\text { opalony', a także 'apetycznie } \\
\text { brązowy' (piernik, czekolada) } \\
\text { i pełni funkcję bardziej } \\
\text { ekspresywną niż opisową. }\end{array}$ \\
\hline$r u d y^{*}$ & rudziutki & 7 & $\begin{array}{l}\text { włosy (dzieciaczek), } \\
\text { sierść (kociak), głównie } \\
\text { w relacji metonimicznej } \\
\text { CAŁOŚĆ ZA CZÉŚC }\end{array}$ & $\begin{array}{l}\text { Użycie hipokorystyku stanowi } \\
\text { we wszystkich przypadkach } \\
\text { wyraz pozytywnych odczuć } \\
\text { mówiącego w stosunku do } \\
\text { opisanej barwy. }\end{array}$ \\
\hline błękitny* & błękitniutki & 2 & niebo & $\begin{array}{l}\text { Hipokorystyk służy do opisania } \\
\text { przyjemnego wrażenia, } \\
\text { jakie wywołuje pogodne, } \\
\text { bezchmurne niebo. Funkcja } \\
\text { ekspresywna zdaje się } \\
\text { dominująca. }\end{array}$ \\
\hline srebrny* & srebrniutki & 2 & $\begin{array}{l}\text { niklowany przedmiot } \\
\text { (np. pistolet) }\end{array}$ & $\begin{array}{l}\text { Hipokorystyk został użyty dla } \\
\text { podkreślenia atrakcyjności } \\
\text { przedmiotów koloru srebrnego } \\
\text { - funkcja raczej ekspresywna } \\
\text { niż opisowa. }\end{array}$ \\
\hline
\end{tabular}




\begin{tabular}{|l|l|l|l|l|}
\hline szary & szarénki & 2 & $\begin{array}{l}\text { Wisła } \\
\text { koniuszek }\end{array}$ & $\begin{array}{l}\text { Funkcja ekspresywna } \\
\text { hipokorystyku wydaje się } \\
\text { dominować nad jego funkcją } \\
\text { opisową we frazie szareńka } \\
\text { Wista, natomiast znaczenie w } \\
\text { drugim przypadku użycia jest } \\
\text { metaforyczne i również wyraża } \\
\text { stan emocjonalny (sympatia, } \\
\text { politowanie). }\end{array}$ \\
\hline
\end{tabular}

\section{Wnioski}

W niniejszej pracy wyróżniono dziewięć sufiksów tworzących hipokorystyki od nazw barw, które zostały zanalizowane w następujący sposób: -ut-ki, -uteń-ki, -ut-eni-ecz-ki, -uś-ki, -usi-eń-ki, -usi-eni-ecz-ki, -eń-ki, -usi, -uch-ny. Następnie, wyodrębniono w nich pięć morfemów odpowiedzialnych za ekspresywny i pieszczotliwy charakter: -ut-, -uch-, -uś-, -eń-, -ecz-. Pod względem kategoryzacji omawiane formacje mają pewne cechy wspólne z trzema klasami derywatów (intensiva, ekspresywizmy, a zwłaszcza hipokorystyki oraz deminutywy), przy czym same pozostają na peryferiach tych kategorii jako elementy nieprototypowe, co spowodowane jest faktem, że wykazują również cechy wspólne z jednostkami zaliczanymi do innych klas wyrazów. Istotnym argumentem przemawiającym za wyróżnieniem kategorii hipokorystyków dla przymiotników jest obecność sufiksów -uch-, -uś-, -eń-, -ecz- zarówno w formacjach rzeczownikowych (np. ciotuchna, mężuś, córeńka, sqsiadeczka), jak i w omawianych przymiotnikach (np. czerwoniuchny, bielusi, szareńki, bielutenieczki). Innym argumentem jest nieskuteczność mechanizmu blokowania paralelnych formacji, która dotyczy omawianej grupy derywatów. Poza tą grupą znajdują się pozostałe formacje ekspresywne, na przykład derywaty z przyrostkami: -aśny i -aśki, których nie cechuje pieszczotliwy charakter, a mechanizm blokowania jest skuteczny: *bielaśny, *bielaśki.

Badanie materiału językowego dostarczonego przez korpus NKJP w jego pełnej wersji (w wersji zrównoważonej jednostek leksykalnych reprezentujących określony w niniejszym artykule typ występuje znacznie mniej) potwierdza wstępne założenie, że podobnie jak w przypadku innych przymiotników, hipokoryzacja wyrazów określających kolory pełni przede wszystkim rolę intensyfikującą - 
w sensie semantycznym, a także rolę wartościująca, w sensie pragmatycznym, przy czym najczęściej wchodzi w grę ewaluacja pozytywna i hipokorystyki używane są dla wyrażenia przyjemnych wrażeń estetycznych, choć niekiedy ma to wydźwięk ironiczny (np. różowiutka twarz sędziego, czyli mało męska, wyglądająca niezbyt poważnie, np., po wypiciu alkoholu, zieloniutka, czyli spleśniała, nieświeża kiełbasa). Zapewne z powodu dominującej jednak tendencji do wyrażania pozytywnych odczuć natury estetycznej bądź emocjonalnej, najczęściej hipokoryzacja dotyczy barw jasnych, budzących optymistyczne, pozytywne skojarzenia a niezbyt często stosuje się takie formy nazywając barwy ciemne, nacechowane raczej negatywnie. Czynnikiem, który zdaje się sprzyjać hipokoryzacji jest potrzeba opisania wyglądu istoty żywej, szczególnie człowieka, i wyrażenia przy tym pewnego stosunku emocjonalnego; stąd zapewne tak wiele przykładów użycia spieszczeń leksemów siwy i różowy, często określających kolor włosów i skóry ludzkiej.

Reasumując, hipokorystyczne formy nazw kolorów zawsze reprezentują pojęcia złożone: w funkcji semantycznej jest to pojęcie podstawowe wzbogacone o koncepcję intensywności, prototypowości barwy (żótciutki kabriolet, zieloniutkie taki), natomiast w funkcji pragmatycznej, ekspresywnej, koncepcja podstawowa wzbogacona jest o informację o atrakcyjności, pozytywnym wrażeniu estetycznym lub/i o ciepłym uczuciu, które dany bodziec wywołuje u mówiącego (btękitniutkie niebo, bielutkie chmurki, rudziutkie dzieciaczki). Bardzo często hipokorystyki barw pełnią obie wspomniane funkcje naraz (różowiutkie policzki; niebieściutkie oczka). W podsumowaniu należy także zaznaczyć, że, pomimo spostrzeżenia Stanulewicz (2009), iż nazwy barw często występują w wyrażeniach metaforycznych, np. czarna/biała magia, Czerwony Październik, zielona ideologia, reprezentując znaczenia niedosłowne, hipokorystyczne formy tych przymiotników na ogół opisują wyłącznie cechy przedmiotów fizycznych, bardzo rzadko nabierając wydźwięku figuratywnego, przy czym nigdy nie jest to znaczenie autonomiczne w stosunku do metaforycznego znaczenia wyrazu podstawowego, a jest ono po prostu przez hipokorystyk intensyfikowane, np. zielone/zieloniutkie pojęcie; różowe/różowiutkie życie; nabiera też sensu emocjonalnego.

Na zakończenie wypada stwierdzić, że przykłady hipokoryzacji nazw kolorów dostarczone przez korpus językowy NKJP wskazują wyraźnie, że są one 
domeną najmniej formalnych rejestrów języka - kolokwialnego i intymnego; większość przykładów użycia pochodzi z forów internetowych, rzadziej z tekstów publicystycznych i stosunkowo rzadko - z literatury pięknej. Wydaje się, wszakże, że w korpusie nie znalazły się wszystkie możliwe hipokorystyczne formy określeń barw, bowiem są one (podobnie jak hipokorystyki innych jednostek leksykalnych) tworzone przez użytkowników często spontanicznie i pod wpływem emocji, co nie sprzyja ich rejestrowaniu w oficjalnych dokumentach.

\section{Bibliografia}

Berlin, Brent; Kay, Paul. 1969. Basic Color Terms: Their Universality and Evolution. University of California Press. Berkeley.

BogusŁawski, Andrzej. 1991. Polski sufiks -utki. Poradnik Jezzykowy 5-6/1991. 174-179. GrzegorczyKowa, Renata. 1981[1972]. Zarys stowotwórstwa polskiego stowotwórstwo opisowe. Wydanie 4. poprawione. Państwowe Wydawnictwo Naukowe. Warszawa.

Kallas, Krystyna. 1999. Przymiotnik. Gramatyka wspótczesnego języka polskiego. Morfologia (trzecie wydanie). Red. Grzegorczykowa, Renata; Laskowski, Roman; Wróbel, Henryk. Wydawnictwo Naukowe PWN. Warszawa. 469-523.

KREJA, BoguSŁaw. 1969. Stowotwórstwo rzeczowników ekspresywnych w języku polskim. Seria monografii Gdańskiego Towarzystwa Naukowego. Gdańsk.

KrejA, Bogustaw. 2002a. O akategorialnym przyrostku ekspresywnym -uchn- (por. mat-uchn-a, mal-uchn-y, płak-uchn-ać). Studia i szkice stowotwórcze. Wydawnictwo UG. Gdańsk. 189-196.

Kreja, Bogustaw. 2002b. O przymiotnikach ekspresywnych na -utki (częściowo też -uśki) w języku polskim. Studia i szkice stowotwórcze. Wydawnictwo UG. Gdańsk. 267-289.

Lakoff, George. 1982. Categories and Cognitive Models. Linguistic Department and Cognitive Science Program. University of California at Berkeley.

Lakoff, George. 1987. Women, Fire and Dangerous Things. The University of Chicago Press. Chicago.

Łoś, JAN. 1925. Gramatyka polska. Cz. 2: Stowotwórstwo. Wydawnictwo Zakładu Narodowego imienia Ossolińskich. Łódź - Warszawa - Kraków.

Marciniak-Firadza, Renata. 2016. Tradycja utrwalona w nazewnictwie stroju ludowego księżaków łowickich. Rozprawy Komisji Językowej ŁTN. LXIII. 53-67.

NKJP = Narodowy Korpus Języka Polskiego. http://nkjp.uni.lodz.pl/ (dostęp: czerwiec - sierpień 2019). 
Polański, Kazimierz. 1999. Encyklopedia Językoznawstwa Ogólnego. Zakład Narodowy imienia Ossolińskich Wydawnictwo. Wrocław - Warszawa - Kraków.

Stownik Języka Polskiego = https://sjp.pl (dostęp 26 lipca 2019).

Stownik staropolski = Nitsch, Kazimierz; Klemensiewicz, Zenon; UrbańczyK, StaniSŁAW (red.). 1953-2002. Słownik staropolski. Polska Akademia Nauk. Warszawa.

Stanulewicz, Danuta. 2009. Colour, Culture and Language. Blue in Polish. Wydawnictwo Uniwersytetu Gdańskiego. Gdańsk.

Szymanek, Bogdan. 2010. A Panorama of Polish Word-Formation. Wydawnictwo KUL. Lublin.

Turner, Mark; Fauconnier, Gilles. 1995. Conceptual Integration and Formal Expression. Journal of Metaphor and Symbolic Activity 10. 183-204. doi.org/10.1207/ s15327868ms1003_3.

Vaillant, André. 1974. Grammaire comparée des langues slaves. Vol. 4: La Formation des Noms. Éditions Klincksieck. Paris.

Wiatrowski, PrzemysŁaw. 2010. Ekspresywizmy leksykalne w „Przewodniku Katolickim” z lat 1895-2005. Peiorativa pierwotne. Poznańskie Studia Polonistyczne Seria Językoznawcza 17 (37). 163-189. doi.org/10.14746/pspsj.2010.17.12.

ŻWAK, IRENA. 1984. Stowotwórstwo przymiotników polskich w jedenastojęzycznym słowniku A. Kalepina z 1590 r. Ossolineum. Wrocław - Warszawa - Kraków - Gdańsk - Łódź.

\section{Are there hypocoristic adjectives in Polish? A Study of Colour Terms}

\section{Abstract}

The descriptive grammars of Polish recognize the category of hypocoristics only in connection with denominal nouns. This research demonstrates that there are good reasons to postulate an adjectival category for hypocoristic formations with regard to derivatives such as bielutki, bielusieńki, bialutki, bieluśki, bieluteńki, bieluchny, bieleńki, bialusieńki, bialuśki, bialuteńki, bielusi. A major argument for this refers to the analysis conducted in this paper, which identifies several recurring morphemes present both in typical nominal hypocoristics and, likewise, in the derived adjectives under investigation. The article also concerns the semantic and pragmatic effects of hypocorization of Polish colour terms in the role of attributive adjectives. A study in the National Corpus of the Polish Language with the aid of the PELCRA search engine into the occurrences of 
such forms confirms that adjectival colour terms perform both the semantic and pragmatic functions of hypocorisms specified in dictionary as well as encyclopaedic definitions of the phenomenon. However, the hypocoristic morphemes attached to colour adjectives, and to unmarked adjectives in antonymous pairs, do not signify a diminished size, but rather signal a positive emotional attitude in the speaker and are used to intensify the description of a colour sensation, i.e., to indicate that a given colour property is recognized in its prime. The pragmatic, emotional load of such terms seems to be no different than in the case of typical, nominal hypocoristic forms; the considered colour terms generally (though not always) express positive speaker attitude.

\section{Postoje li hipokoristični pridjevi u poljskome? Istraživanje naziva za boje}

\section{Sažetak}

Deskriptivne gramatike poljskoga jezika navode kategoriju hipokoristika samo u vezi s odimenskim izvedenicama. Ovo istraživanje pokazuje da postoje dobri razlozi da se postulira pridjevska kategorija za hipokoristične formacije s obzirom na izvedenice kao što su: bielutki, bielusieńki, bialutki, bieluśki, bieluteńki, bieluchny, bieleńki, bialusieńki, bialuśki, bialuteńki, bielusi. Glavni argument za to jest analiza provedena u ovome radu, koja određuje nekoliko morfema koji se ponavljaju, a prisutni su i kod tipičnih nominalnih hipokoristika i kod ovdje analiziranih izvedenih pridjeva. Ovaj rad dotiče se i semantičkih i pragmatičkih efekata tvorbe hipokoristika od poljskih naziva za boje u ulozi atributivnih pridjeva. Istraživanje takvih oblika u Nacionalnome korpusu poljskoga jezika uz pomoć tražilice PELCRA potvrđuje da pridjevski nazivi za boje imaju i semantičke i pragmatičke funkcije hipokoristika koje su određene u rječničkim i enciklopedijskim definicijama. Međutim, hipokoristični morfemi povezani s pridjevima za boje, kao i uz neoznačene pridjeve u antonimnim parovima, ne znače umanjenu veličinu, nego upućuju na pozitivan emocionalni stav govornika te se upotrebljavaju da pojačaju opis doživljaja boje, npr. da upute na to da je određeno svojstvo boje prepoznato u svojoj najvećoj mjeri. Čini se da pragmatički, emocionalni naboj takvih termina nije drukčiji nego u slučaju tipičnih, 
nominalnih hipokorističnih oblika; razmotreni nazivi za boje općenito (iako ne uvijek) izražavaju pozitivan stav govornika.

Słowa kluczowe: hipokorystyk, ekspresywy, kolory, morfologia, funkcje, słowotwórstwo polskie

Keywords: hypocorism, expressives, colours, morphology, functions, Polish word-formation Ključne riječi: hipokoristik, ekspresivni pridjevi, boje, morfologija, funkcije, poljska tvorba riječi 